\title{
PENERAPAN STRATEGI PEMBELAJARAN EVERYONE IS A TEACHER HERE UNTUK MENINGKATKAN MORAL SISWA
}

\author{
Arif Syafi'i $^{1}$, Fahrudin ${ }^{2}$, Misrodin $^{3}$, Bambang Ariyanto $^{4}$, Tri Alim Saputra H. ${ }^{5}$ \\ $1,2,3,4,5$ Universitas Nahdlatul Ulama Lampung, Lampung, Indonesia
}

\section{Informasi Artikel}

Riwayat Artikel:

Diserahkan: 19-09-2020

Direvisi: $19-10-2020$

Dipublikasikan: 11-01-2021

\section{Kata-kata kunci:}

Everyone is a Teacher Here

Moral Siswa

Pendidikan

Kewarganegaraan

\begin{abstract}
ABSTRAK
Penulis melakukan penelitian bertujuan untuk mengetahui peningkatan moral melalui penerapan strategi pembelajaran Everyone is a Teacher Here di MIN 1 Lampung Timur. Metode penelitian yang digunakan dalam penelitian ini adalah Penelitian Tindakan Kelas dengan menerapkan dua siklus, terdiri dari 4 tahapan yang meliputi: perencanaan, pelaksanaan tindakan, observasi dan refleksi. Data penelitian dikumpulkan dari observasi selama pembelajaran dengan menggunakan eksperimen dengan penilaian tindakan berupa aktivitas guru dalam menerapkan strategi pembelajaran Everyone is a Teacher Here dan aktivitas peserta didik untuk mengetahui aktivitas moral yang ditunjukkan oleh siswa. siswa selama pembelajaran. Hasil penelitian menunjukkan bahwa terdapat peningkatan moral dengan penerapan strategi pembelajaran Everyone is a Teacher Here di MIN 1 Lampung Timur.
\end{abstract}

This is an open access article under the CC BY-SA license.

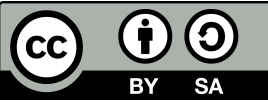

\section{Penulis Korespondensi:}

Arif Syafi'i,

Universitas Nahdlatul Ulama Lampung,

Mataram Marga, Sukadana, Kabupaten Lampung Timur, Lampung, Indonesia.

Email: syafiiarifsyafii@gmail.com

\section{PENDAHULUAN}

Keberhasilan suatu bangsa dalam memperoleh tujuannya tidak hanya ditentukan oleh melimpahnya sumber daya alam, akan tetapi sangat ditentukan oleh kualitas sumber daya manusianya. Bangsa yang besar dapat dilihat dari kualitas/karakter bangsa itu sendiri. Karakter adalah mustika hidup yang membedakan manusia dengan binatang. Orang-orang yang berkarakter kuat dan baik secara individual maupun sosial ialah mereka yang memiliki akhlak, moral, dan budi pekerti yang baik. Mengingat begitu pentingnya karakter, maka institusi pendidikan memiliki tanggung jawab untuk menanamkannya melalui proses pembelajaran.

Penguatan pendidikan karakter dalam konteks sekarang sangat relevan untuk mengatasi krisis moral yang sedang terjadi di negara kita. Diakui atau tidak diakui saat ini terjadi krisis yang nyata dan mengkhawatirkan dalam masyarakat dengan melibatkan milik kita yang paling berharga, yaitu anak-anak. Krisis itu antara lain berupa meningkatnya pergaulan seks bebas, maraknya angka kekerasan anak-anak dan remaja, kejahatan terhadap teman, pencurian remaja, dan penyalahgunaan obat-obatan, pornografi, perkosaan, perampasan, dan perusakan milik orang lain sudah menjadi masalah sosial yang hingga saat ini belum dapat diatasi secara tuntas. Perilaku remaja juga diwarnai dengan kebiasaan bullying di sekolah dan tawuran. Akibat yang ditimbulkan cukup serius dan tidak dapat lagi dianggap sebagai suatu persoalan sederhana karena tindakan ini telah menjurus kepada tindakan kriminal (Zubaedi, 2011). 
Tujuan dari pengembangan perilaku moral adalah cara untuk mengembangkan kemampuan yang dimiliki anak dalam hal mengaplikasikan seperangkat standar dalam perbuatan dan sikap ketika berinteraksi di dalam kehidupannya sehari-hari baik dengan dirinya dan orang lain. Misalkan jika anak dapat bersikap sopan terhadap guru di sekolah maka anak akan mendapatkan pengakuan, berupa penilaian yang baik dari guru dan teman sebayanya, juga sebaliknya apabila anak bersikap tidak hormat pada guru maka ia akan mendapatkan peniiaian yang buruk dari lingkungan sosialnya yakni teman-teman di sekolah. Anak juga sudah dapat menyesuaikan dlri dengan yang diinginkan kelompok sosialnya dan mana yang harus dijauhi anak mulai patuh terhadap tuntutan atau aturan dari orang tua dan lingkungan sosialnya. Akan tetapi dalam kenyataannya, di MIN 1 Lampung Timur terjadi ketidaksesuaian dengan yang diharapkan.

Melalui penelitian tindakan ini peneliti bermaksud memberikan kontribusi positif dalam upaya meningkatkan perilaku moral siswa melalui penerapan strategi pembelajaran Everyone is a Teacher Here di MIN 1 Lampung Timur. Tujuan dalam penelitian ini untuk mengetahui: 1) Peningkatan moral melalui penerapan strategi pembelajaran Everyone is a Teacher Here di MIN 1 Lampung Timur. 2) Penerapan strategi pembelajaran Everyone Is A Teacher Here dapat meningkatkan moral di MIN 1 Lampung Timur.

\section{METODE PENELITIAN}

Penelitian tindakan kelas ini peneliti mengambil lokasi di MIN 1 Adirejo kecamatan Pekalongan kabupaten Lampung Timur. Jenis penelitian yang digunakan dalam penelitian ini adalah Penelitian Tindakan Kelas (PTK). PTK sangat cocok untuk penelitian ini, karena penelitian diadakan di dalam kelas dan lebih difokuskan pada masalah-masalah yang terjadi di dalam kelas atau pada proses belajar mengajar sebagai upaya untuk memperbaiki proses pembelajaran serta meningkatkan kemampuan siswa.

Pendekatan yang digunakan dalam penelitian ini adalah pendekatan deskriptif. Apabila datanya telah terkumpul lalu diklasifikasikan menjadi dua kelompok data, yaitu kuantitatif yang berbentuk angka-angka dan data kualitatif yang dinyatakan dalam kata-kata atau simbol. Data kualitatif yang berbentuk kata-kata tersebut disisihkan untuk sementara, karena akan sangat berguna untuk menyertai dan melengkapi gambaran yang diperoleh dari analisis data kuantitatif (Arikunto, 2012). Sehingga dalam penelitian ini diperlukan dulu data kuantitatif yang berbentuk angka, setelah itu baru diperjelas dengan kata-kata.

Penelitian ini menggunakan model PTK Kemmis \& Mc. Taggart yang dalam alur penelitiannya yakni meliputi langkah-langkah: (1) Perencanaan (planning). (2) Aksi atau tindakan (acting). (3) Observasi (observing). (4) Refleksi (reflecting) (Aqib, 2006; Erfan \& Ratu, 2017; Erfan, Sari, Suarni, Maulyda, \& Indraswati, 2020). Pada tahapan ini biasanya disebut dengan satu siklus. Sehingga penelitian ini merupakan proses siklus spiral, mulai dari perencanaan, pelaksanaan tindakan, pengamatan, dan refleksi. Siklus ini akan terus berlanjut dan akan dihentikan oleh peneliti apabila ketercapaian keberhasilan indikator yang telah ditentukan.

Model Kemmis \& Mc. Taggart merupakan pengembangan dari konsep dasar yang diperkenalkan oleh Kurt Lewin, hanya saja komponen acting (tindakan) dan observing (pengamatan) dijadikan sebagai satu kesatuan. Disatukannya kedua komponen tersebut disebabkan oleh adanya kenyataan bahwa penerapan antara acting dan observing merupakan dua kegiatan yang tidak terpisahkan (Wahidmurti, 2008). Maksudnya, kedua kegiatan haruslah dilakukan dalam satu kesatuan waktu, jadi jika berlangsungnya suatu tindakan begitu pula observasi juga dilakukan.

Penelitian mengenai meningkatkan moral siswa dengan strategi "Everyone is a Teacher Here" ini menggunakan penelitian tindakan kelas (classroom action research). Dalam penelitian ini penulis akan berusaha mengkaji dan merefleksi suatu pendekatan pembelajaran dengan tujuan meningkatkan moral siswa. Penelitian ini akan dilakukan sebagai upaya mengatasi permasalahan yang muncul di dalam kelas. Salah satunya adalah moral siswa, yang dirasa oleh penulis masih terdapat permasalahan dalam proses pembelajarannya.

\subsection{Kriteria Keberhasilan Tindakan}

Keberhasilan kinerja dengan penerapan strategi pembelajaran everyone is a Teacher Here untuk meningkatkan moral siswa pada mata pelajaran PKN dengan indikator moral siswa dalam pembelajaran PKN sebesar $\geq 75$ dengan kriteria sekurang-kurangnya baik.

Memudahkan dalam mencari tingkat keberhasilan tindakan, sebagaimana yang dikatakan Mulyasa (2005) bahwa kualitas pembelajaran didapat dari segi proses dan dari segi hasil. Dari segi proses, pembelajaran dikatakan berhasil dan berkualitas apabila seluruhnya atau setidak-tidaknya sebagian besar 75\% siswa terlibat secara aktif, baik secara fisik, mental maupun sosial dalam proses pembelajaran. Di samping itu menunjukkan kegairahan belajar yang tinggi, semangat yang besar dan percaya pada diri sendiri. 
Kriteria keberhasilan tindakan ini akan dilihat dari indikator proses pada pembelajaran pada mata pelajaran PKN dengan komponen-komponen yang menjadi indikator moral dalam penelitian ini meliputi 7 hal sebagai berikut: 1) Percaya diri dalam mengungkapkan pendapat, 2) Mengambil keputusan berdasarkan pertimbangan yang matang, 3) Bekerjasama dalam kelompok, 4) Percaya diri saat mempresentasikan tugas, 5) Menghargai pendapat orang lain, 6) Menolong teman yang membutuhkan bantuan, 7) Mengkritik pendapat orang lain.

\subsection{Teknik Pengumpulan Data}

Teknik pengumpulan data yang digunakan dalam penelitian ini adalah Lembar observasi aktivitas guru berfungsi untuk mengamati dan mengevaluasi keterampilan guru dalam menyampaikan materi dan mengendalikan kelas selama proses belajar-mengajar berlangsung yang dinilai oleh para pengamat (observer) yang dipilih oleh peneliti sesuai kriteria yang telah ditentukan. Lembar observasi aktivitas guru ini berisi penilaian kepada guru yang mengajar.

Lembar observasi aktivitas siswa adalah lembar pengamatan yang digunakan untuk mengamati aktivitas siswa selama proses belajar-mengajar berlangsung pada mata pelajaran PKN dengan strategi Everyone Is A Teacher Here. Lembar observasi ini pun sama dengan lembar observasi guru yang dinilai oleh pengamat (observer) yang sama untuk mengamati siswa di kelas selama pembelajaran berlangsung.

\subsection{Teknik Analisa Data}

Jenis data yang diperoleh adalah data kuantitatif dan data deskriptif kualitatif. Data kuantitatif meliputi data moral siswa pada saat siswa menyampaikan pendapatnya saat diskusi yang diperoleh dari penilaian selama pembelajaran berlangsung. Analisis data dilakukan setiap akhir siklus sesuai dengan prosedur analisis.

\section{HASIL DAN PEMBAHASAN}

Penelitian tindakan kelas kolaboratif telah dilaksanakan di MIN 1 Lampung Timur. Penelitian tersebut menerapkan strategi pembelajaran Everyone is a Teacher Here untuk meningkatkan moral siswa pada pembelajaran PKN. Ini memaparkan tentang (1) deskripsi data dan (2) pembahasan hasil penelitian. Pelaksanaan tindakan kelas dilakukan sebanyak 2 siklus dimana setiap siklus terdiri dari 2 pertemuan dengan alokasi waktu $2 \times 35$ menit tiap pertemuan.

\subsection{Deskripsi Pelaksanaan Tindakan Kelas Siklus I}

Tindakan pembelajaran siklus I dilaksanakan pada hari Selasa, 18 April 2017 pukul 07.00 hingga 08.45 dengan alokasi waktu 3 jp $(3 \times 35)$. Materi yang dibelajarkan guru yaitu Pengaruh Globalisasi sub materi kita di tengah-tengah globalisasi. Hasil pelaksanaan tindakan siklus I meliputi aktivitas guru, aktivitas, dan moral siswa.

Data aktivitas guru diperoleh dari hasil pengamatan terhadap guru mitra dalam perencanaan dan pelaksanaan pembelajaran PKN dengan menerapkan strategi pembelajaran Everyone is a Teacher Here. Hasil pengamatan terhadap kemampuan guru dalam merencanakan kegiatan pembelajaran siklus I aktivitas guru dalam merencanakan kegiatan pembelajaran aspek yang belum dinilai baik yaitu: (1) sikap guru dalam proses pembelajaran dengan strategi Everyone is a Teacher Here, (2) Penilaian dalam proses pembelajaran, dan (3) kemampuan dalam menggunakan media.

Secara umum, perencanaan pembelajaran yang dilakukan guru sudah cukup baik, namun masih perlu perbaikan pada beberapa aspek agar hasil yang diperoleh lebih optimal. Penilaian moral siswa yang dilakukan pada siklus I meliputi dimensi moral antara lain: sikap kejujuran siswa, tangggung jawab pribadi maupun kelompok, memiliki kemampuan visioner yang luas dalam pembelajaran, disiplin dalam pembelajaran, bekerjasama dalam kelompok, mampu bersikap adil, dan peduli terhadap sesama teman. Moral siswa pada pembelajaran PKN menggunakan strategi Everyone is a Teacher Here menunjukkan moral yang baik tetapi belum memenuhi indikator keberhasilan yang ditetapkan yaitu 75 .

\subsection{Deskripsi Pelaksanaan Tindakan Kelas Siklus II}

Pelaksanaan kegiatan pembelajaran siklus II merupakan tindak lanjut dari hasil kegiatan pembelajaran siklus I. Kegiatan pembelajaran siklus II dilaksanakan pada hari Senin, 29 April 2017 pukul 07.00 hingga 08.45 WIB. Materi yang dibelajarkan guru yaitu materi tentang sikap terhadap globalisasi di lingkungannya dengan sub materi jenis budaya Indonesia yang pernah ditampilkan dalam misi kebudayaan internasional dan sikap 
terhadap pengaruh globalisasi yang terjadi di lingkungannya. Alokasi waktu yang digunakan sebanyak $2 \times 35$ menit atau 2 jam pertemuan.

Aktivitas guru diperoleh dari hasil pengamatan terhadap guru mitra dalam perencanaan dan pelaksanaan pembelajaran PKN dengan menerapkan strategi pembelajaran Everyone is a Teacher Here. Hasil pengamatan terhadap kemampuan guru dalam merencanakan kegiatan pembelajaran. Langkah-langkah pembelajaran menggunakan strategi pembelajaran Everyone is a Teacher Here pada skenario pembelajaran sudah terlihat cukup jelas, guru juga telah menyiapkan berbagai pertanyaan dengan cukup baik.

Secara umum, perencanaan pembelajaran yang dilakukan guru sudah cukup baik, Moral siswa yang dilakukan pada siklus II mayoritas siswa menunjukkan bahwa moral setiap siswa telah menunjukkan moral sangat baik, sedangkan rata-rata dari skor total yaitu 3,2 atau jika dikonversikan pada nilai 3.20 $\times 100 / 4=80.12$ hal ini menunjukkan moral siswa memiliki kategori sangat baik. Berdasarkan hasil tersebut, dapat dinyatakan bahwa moral siswa pada siklus II telah menunjukkan sangat baik dan telah memenuhi indikator keberhasilan yang ditetapkan yaitu 75 .

\section{SIMPULAN}

Berdasarkanan alisis data dan pembahasan, peneliti menyimpulkan penerapan strategi pembelajaran Everyone is a Teacher Here dapat meningkatkan aktivitas guru dan moral siswa siswa pada pelajaran PKN materi Pengaruh Globalisasi di kelas IV MIN 1 Lampung Timur. Aktivitas guru dalam perencanaan dan pelaksanaan pembelajaran dalam menerapkan strategi pembelajaran Everyone is a Teacher Here pada pembelajaran PKN materi Pengaruh Globalisasi sudah baik. Nilai aktivitas guru pada siklus I mencapai 84,5 dengan kategori baik, kemudian pada siklus II aktivitas guru meningkat menjadi 87,9 dengan kategori sangat baik. Berdasarkan data tersebut, telah terjadi peningkatan aktivitas guru sebesar 3,4 atau 4\%. Nilai moral siswa setelah menerapkan strategi pembelajaran Everyone is a Teacher Here pada pembelajaran PKN materi Pengaruh Globalisasi mengalami peningkatan. Perolehan moral siswa pada siklus I untuk rata-rata nilai yaitu pada siklus I sebesar 73,57, kemudian pada siklus II moral siswa meningkat menjadi 80,12. Berdasarkan data tersebut, terjadi peningkatan pada siklus II sebesar 6,55 atau $9 \%$.

\section{DAFTAR PUSTAKA}

Aqib, Z. (2006). Penelitian Tindakan Kelas. Bandung: Yrama Widya.

Arikunto, S. (2012). Prosedur Penelitian : Suatu Pendekatan Praktik (Edisi Revisi). Jakarta: Rineka Cipta.

Erfan, M., \& Ratu, T. (2017). Meningkatkan Minat Dan Hasil Belajar Mahasiswa Pada Perkuliahan Elektronika Dasar Melalui Digital Game-Based Learning. Meningkatkan Minat Dan Hasil Belajar Mahasiswa Pada Perkuliahan Elektronika Dasar Melalui Digital Game-Based Learning, 332-337. doi:S0962-8924(12) 00067-0[pii] \n10.1016/j.tcb.2012.04.004

Erfan, M., Sari, N., Suarni, N., Maulyda, M. A., \& Indraswati, D. (2020). Peningkatan Hasil Belajar Kognitif Melalui Model Pembelajaran Kooperatif Tipe Numbered Head Together (NHT) Tema Perkalian dan Pembagian Pecahan. JURNAL IKA : IKATAN ALUMNI PGSD UNARS, 8(1), 108-118. doi:10.36841/ pgsdunars.v8i1.588

Mulyasa, E. (2005). Menjadi Guru Profesional Menciptakan Pembelajaran Kreatif dan Menyenangkan. Bandung: Remaja Rosda.

Wahidmurti, N. A. (2008). Penelitian tindakan kelas pendidikan agama dan umum dari teori menuju praktik disertai contoh hasil penelitian. Malang: Universitas Negeri Malang.

Zubaedi. (2011). Desain Pembelajaran Karakter. Jakarta: Kencana Prenada. 